\title{
KARAKTERISTIK LINGKUNGAN DAN INFRASTRUKTUR KAITANNYA DENGAN TINGKAT KESIAPSIAGAAN DI KAWASAN RAWAN BENCANA ERUPSI MERAPI
}

\author{
Oleh: \\ Nurhadi, Arif Ashari, dan Suparmini \\ Jurusan Pendidikan Geografi FIS UNY \\ nurhadi fise@uny.ac.id
}

\begin{abstract}
Abstrak
Penelitian ini dilaksanakan pada kawasan rawan bencana II dan III Gunung Merapi dengan tujuan: (1) Membangun basisdata spasial mengenai kondisi lingkungan dan infrastruktur pada kawasan rawan bencana lereng selatan Gunung Merapi, (2) Menganalisis pengaruh kondisi lingkungan pada saat ini terhadap kesiapsiagaan dalam menghadapi bencana, (3) Menganalisis perbedaan kondisi lingkungan antar wilayah permukiman dalam mempengaruhi tingkat kesiapsiagaan menghadapi bencana. Pengumpulan data dilakukan dengan wawancara, observasi, dan dokumentasi. Analisis yang digunakan adalah analisis deskriptif dengan didukung analisis statistik dan analisis keruangan. Hasil penelitian (1) Basisdata lingkungan fisik yang disusun meliputi kondisi geologis, geomorfologis, dan hidrologis, ditambah dengan infrastruktur yang berkaitan dengan pengurangan risiko bencana. (2) Kondisi lingkungan fisik menentukan jenis bahaya erupsi sedangkan infrastruktur berpengaruh terhadap penanganan situasi darurat bencana. Wilayah permukiman yang memiliki kondisi lingkungan fisik lebih berbahaya cenderung membentuk tingkat kesiapsiagaan yang tinggi. (3) Aspek kondisi lingkungan fisik yang menghasilkan perbedaan bahaya sehingga mempengaruhi kesiapsiagaan terutama adalah ketinggian tempat, jarak dari pusat erupsi, jarak dari alur sungai utama, serta faktor hidrologis yang menentukan potensi sumberdaya air permukaan.
\end{abstract}

Kata kunci: Kesiapsiagaan, bencana, erupsi, Merapi

\begin{abstract}
This research was conducted in disaster prone areas II and III of Merapi Volcano which aimed at: (1) developing spatial databases on environmental and infrastructure conditions in disaster-prone areas of southern slopes of Merapi Volcano, (2) analyzing the effect of current environmental conditions on disaster preparedness, and (3) analyzing the difference of environmental conditions among settlement areas in influencing the disaster preparedness level. Data collection techniques include interviews, observations, and documentations. The analysis used in this research is a descriptive analysis supported by statistical and spatial analysis. The results are: (1) The database developed includes geological, geomorphological, and hydrological conditions, completed with infrastructure related to disaster risk reduction. (2) Physical environment conditions determine the type of eruption hazard while the infrastructure influences the strategies to deal with emergency disaster situations. The settlement areas which have more dangerous physical environment conditions tend to create a high level of preparedness. (3) Aspects of physical environmental conditions which produce different hazards and influence preparedness are mainly altitude, distance from the eruption center, distance from the main river channel, and hydrological factors that determine the potential of surface water resources.
\end{abstract}

Keywords: Preparedness, disaster, eruption, Merapi 
Karakteristik Lingkungan dan Infrastruktur Kaitannya dengan Tingkat Kesiapsiagaan di Kawasan Rawan Bencana Erupsi Merapi

\section{PENDAHULUAN}

Kedudukan Pulau Jawa yang terletak pada zona tumbukan antara Lempeng Asia Tenggara dengan Lempeng Hindia Australia menyebabkan wilayah ini banyak terpengaruh oleh berbagai fenomena hasil proses subduksi. Salah satu dampak proses subduksi yang menonjol di Pulau Jawa adalah banyaknya aktivitas vulkanisme. Verstappen (2013) menjelaskan bahwa Pulau Jawa merupakan wilayah dengan tingkat vulkanisme tertinggi di Indonesia. Berdasarkan catatan sejarah erupsi, Pulau Jawa mengalami 470 kali erupsi atau 47\% erupsi total yang pernah terjadi di Indonesia, serta terdapat 23 gunungapi tipe A. Sementara itu disisi lain Pulau Jawa juga memiliki jumlah penduduk dan kepadatan penduduk tertinggi di Indonesia. Hasil sensus tahun 2010 menunjukkan jumlah penduduk di seluruh provinsi di Pulau Jawa mencapai 136.610 .608 jiwa (BPS, 2017). Kondisi ini menyebabkan risiko bencana akibat erupsi masih relatif tinggi pada masa yang akan datang.

Gunung Merapi di Jawa Tengah merupakan vulkan yang paling aktif diantara 23 vulkan tipe A yang terdapat di Pulau Jawa. Wilayah Gunung Merapi juga banyak ditempati oleh penduduk yaitu di Kabupaten Sleman Provinsi DIY, serta Kabupaten Magelang, Boyolali, dan Klaten, Provinsi Jawa Tengah. Pasca bencana erupsi pada tahun 2010 tingkat hunian penduduk di kawasan rawan bencana erupsi Gunung Merapi relatif masih tinggi bahkan mengalami peningkatan di beberapa tempat. Sudibyakto (2011) menjelaskan, peningkatan pertumbuhan penduduk di wilayah sekitar Gunung Merapi sebesar 2,8\%, melebihi rata-rata pertumbuhan penduduk nasional sebesar 2,5\%. Hal ini tidak terlepas dari banyaknya potensi sumberdaya di kawasan tersebut yang berupa sumberdaya lahan, sumberdaya air, sumberdaya hayati, dan sumberdaya mineral (Sutikno dkk, 2007).

Ancaman bahaya erupsi ditambah dengan meningkatnya jumlah penduduk rentan di daerah rawan bencana menyebabkan risiko bencana akibat erupsi relatif masih tinggi pada masa mendatang. Kondisi ini mengisyaratkan kegiatan pengelolaan kebencanaan yang telah dilakukan selama ini perlu untuk terus ditingkatkan dari waktu ke waktu. Kegiatan pengelolaan kebencanaan agar dapat terlaksana dengan baik perlu didukung salah satunya dengan ketersediaan data keruangan yang akurat, mencakup berbagai aspek terkait dengan pengurangan risiko bencana. Data-data bereferensi spasial yang mendesak untuk disediakan antara lain data yang berkaitan dengan bahaya, kerentanan, dan kesiapsiagaan seperti persebaran penduduk rentan, kondisi jalur evakuasi, persebaran lokasi evakuasi, distribusi sumberdaya pendukung evakuasi, dan sebagainya. Pengelolaan kebencanaan sangat penting untuk membangun sistem kehidupan masyarakat yang selaras dengan ancaman bencana sehingga masyarakat tetap dapat bertempat tinggal dan memanfaatkan berbagai potensi sumberdaya yang ada sekaligus menghindari timbulnya korban dan kerugian apabila terjadi bencana erupsi.

Dalam kurun waktu tujuh tahun pasca bencana erupsi terakhir yang terjadi pada tahun 2010 tentunya pada kawasan rawan bencana III Gunung Merapi telah banyak terjadi perubahan kondisi fisik, sosial, termasuk infrastuktur wilayah untuk evakuasi bencana. Berdasarkan kondisi ini maka pembaruan data-data perlu dilakukan yang dapat dimanfaatkan sebagai referensi untuk pelaksanaan pengelolaan kebencanaan dalam 
menghadapi ancaman bencana yang masih dapat terjadi pada masa mendatang. Selain itu perlu diketahui pula apakah kondisi lingkungan saat ini berpengaruh terhadap kesiapsiagaan organisasi penanggulangan risiko bencana pada masing-masing wilayah, serta apakah ada pengaruh perbedaan kondisi fisik dan insfrastruktur terhadap kesiapsiagaan antara wilayah satu dengan lainnya.

Wilayah lereng selatan Gunung Merapi merupakan wilayah yang paling banyak terdampak oleh erupsi pada tahun 2010. Badan Geologi melalui Peta Kawasan Rawan Bencana Gunung Merapi dan Area Terdampak Letusan 2010 menunjukkan wilayah terdampak langsung letusan 2010 terdapat di lereng selatan Gunung Merapi. Dampak erupsi di wilayah ini antara lain korban jiwa, kerusakan permukiman, infrastruktur, serta vegetasi yang terbakar. Selain itu dampak erupsi di lereng selatan Gunung Merapi juga menyebabkan perubahan kondisi geomorfik (Belizal dkk, 2013). Dengan kondisi tersebut, wilayah ini dimungkinkan mengalami perubahan paling banyak akibat bencana erupsi dibandingkan wilayah lainnya. Oleh karena itu pembaruan data spasial untuk wilayah ini sangat diperlukan dalam mendukung pengelolaan kebencanaan yang dilakukan. Pembaruan data bermanfaat untuk digunakan sebagai bahan rekomendasi dalam pelaksanaan pengelolaan kebencanaan.

\section{METODE}

Penelitian ini merupakan penelitian deskriptif yang bertujuan untuk menjelaskan gejala-gejala yang dijumpai secara terperinci. Pendekatan yang digunakan dalam penelitian ini adalah pendekatan geografi yaitu pendekatan keruangan yaitu melihat daerah penelitian sebagai suatu ruang dengan berbagai komponen di dalamnya. Tema pendekatan keruangan yang digunakan dalam penelitian ini adalah tema analisis pola keruangan, analisis struktur keruangan, dan analisis sistem keruangan. Pemilihan penggunaan tema dalam pendekatan ini sesuai dengan tujuan penelitian yaitu untuk mengidentifikasi kondisi lingkungan dan infrastruktur, menjabarkannya melalui penyusunan basisdata spasial, serta melihat adanya hubungan dengan kesiapsiagaan dalam menghadapi bencana.

Populasi dalam penelitian ini adalah seluruh wilayah lereng selatan Gunung Merapi beserta elemen sosial budayanya pada kawasan rawan bencana II dan III. Pengambilan sampel aspek fisik untuk mengidentifikasi kondisi lingkungan fisik dan infrastruktur dilakukan dengan teknik purposif sampling yaitu pada beberapa wilayah permukiman yang tersebar antara satuan bentuklahan lereng gunungapi, kaki gunungapi, dan dataran kaki gunungapi. Terdapat 27 wilayah permukiman yang digunakan sebagai sampel pengamatan berdasarkan variasi satuan bentuklahan, jarak dari pusat erupsi, dan jarak dari alur sungai utama. Pengambilan sampel untuk mengetahui tingkat kesiapsiagaan juga dilakukan dengan teknik purposif sampling yaitu pada anggota masyarakat yang berperan dalam organisasi pengurangan risiko bencana.

Pengumpulan data dilakukan dengan wawancara, observasi, dokumentasi, dan studi pustaka. Analisis yang digunakan adalah analisis deskriptif dengan didukung analisis statistik dan analisis keruangan. Untuk menjawab tujuan penelitian pertama digunakan 
Karakteristik Lingkungan dan Infrastruktur Kaitannya dengan Tingkat Kesiapsiagaan di Kawasan Rawan Bencana Erupsi Merapi

analisis deskriptif yaitu dengan memperhatikan kondisi fisik lingkungan dan faktor-faktor yang mempengaruhinya. Selanjutnya untuk menjawab rumusan masalah ke dua digunakan analisis statistik dengan menggunakan regresi linear. Untuk menjawab rumusan masalah ke tiga digunakan analisis deksriptif analitik untuk menunjukkan perbedaan faktor lingkungan fisik yang mempengaruhi kesiapsiagaan.

\section{HASIL DAN PEMBAHASAN}

\section{Daerah Penelitian}

Penelitian ini dilaksanakan pada kawasan rawan bencana (KRB) erupsi Lereng Selatan Gunung Merapi, yang mencakup KRB II dan KRB III. Pemilihan kawasan rawan bencana erupsi para Lereng Selatan Gunung Merapi dengan pertimbangan daerah ini paling banyak terkena dampak erupsi pada saat terjadi bencana erupsi tahun 2010. Dampak erupsi berupa korban jiwa dan kerugian materi serta dampak terhadap kondisi bentanglahan. Sutawidjaja (2013) menjelaskan, dibandingkan dengan letusan terdahulu pada tahun 1994 dan 2006, sejak 26 Oktober 2010 karakteristik letusan Merapi berubah menjadi letusan eksplosif vertikal yang dianggap sebagai letusan tipe lain dari Merapi. Letusan terarah secara mendadak pada pukul 17.02 tanggal tersebut ke arah Lereng Selatan Gunungapi Merapi menyebabkan sekitar tiga puluh orang tewas. Belizal dkk (2013) menjelaskan erupsi tahun 2010 menghasilkan material piroklastik 10 kali lebih banyak dibandingkan tahun 1994 dan 2006. Pada lereng distal pasca erupsi lahar hujan menyebabkan dampak yang sangat luas dalam bentuk kerusakan bangunan maupun dampak geomorfik. Sementara itu berdasarkan Peta Kawasan Rawan Bencana Gunung Merapi dan Area Terdampak Letusan 2010 Skala 1:50.000 yang diterbitkan oleh Badan Geologi, lereng selatan merupakan wilayah yang terdampak langsung letusan tahun 2010.

Daerah penelitian secara astronomis terletak pada 430156 MT hingga 441484 MT serta $9154934 \mathrm{MU}$ hingga $9166320 \mathrm{MU}$ dalam koordinat UTM zona 49S. Secara administratif daerah penelitian terletak di wilayah Kabupaten Sleman yaitu mencakup Kecamatan Turi, Pakem, dan Cangkringan yang terletak diantara lembah Sungai Krasak di Bagian Barat dan Sungai Gendol di Bagian Timur. Luas daerah penelitian adalah 61,13 km². Daerah penelitian berbatasan dengan wilayah Provinsi Jawa Tengah di bagian utara, barat, dan timur, serta wilayah Kabupaten Sleman di bagian selatan (Gambar 1).

Daerah penelitian secara geologis tersusun oleh material hasil erupsi Gunungapi Merapi yang terdiri dari Endapan Gunungapi Merapi Tua (Qmo) dan Endapan Gunungapi Merapi Muda (Qmi). Endapan Gunungapi Merapi Tua hanya sedikit dijumpai di daerah penelitian dan menjadi material penyusun Bukit Turgo dan Plawangan, sedangkan endapan Gunungapi Merapi Muda mendominasi daerah penelitian. Gunung Merapi merupakan vulkan tipe strato. Secara geomorfologis vulkan strato yang masih aktif memiliki bentuklahan yang sangat kompleks mulai dari puncak hingga bagian bawahnya. Verstappen (2013) membedakan morfologi gunungapi secara umum menjadi tiga segmen yaitu bagian atas, tengah, dan bawah. Ketiga sektor tersebut dibatasi oleh dua takik lereng. Lereng paling atas dengan morfologi paling terjal terbentuk oleh abu dan atau klastik yang berasal dari hancuran sumbat lava, jatuhan atau longsor di bawah pengaruh gravitasi. Zona 
kedua dengan transport basah oleh lahar membentuk lereng fluviovulkanik. Zona ketiga terbentuk oleh endapan fluvial. Simoen (2001) dan Sutikno dkk (2007) menjabarkan satuan morfologi gunungapi strato menjadi lebih rinci yaitu kerucut vulkan, lereng vulkan, kaki vulkan, dataran fluvio kaki vulkan, dan dataran fluviovulkan. Selain itu perbedaan struktur dan proses pembentukan terdapat secara spesifik dan setempat pada kawah, kubah lava, medan lava, sumbat lava, medan lahar, baranco, dan kerucut parasiter.

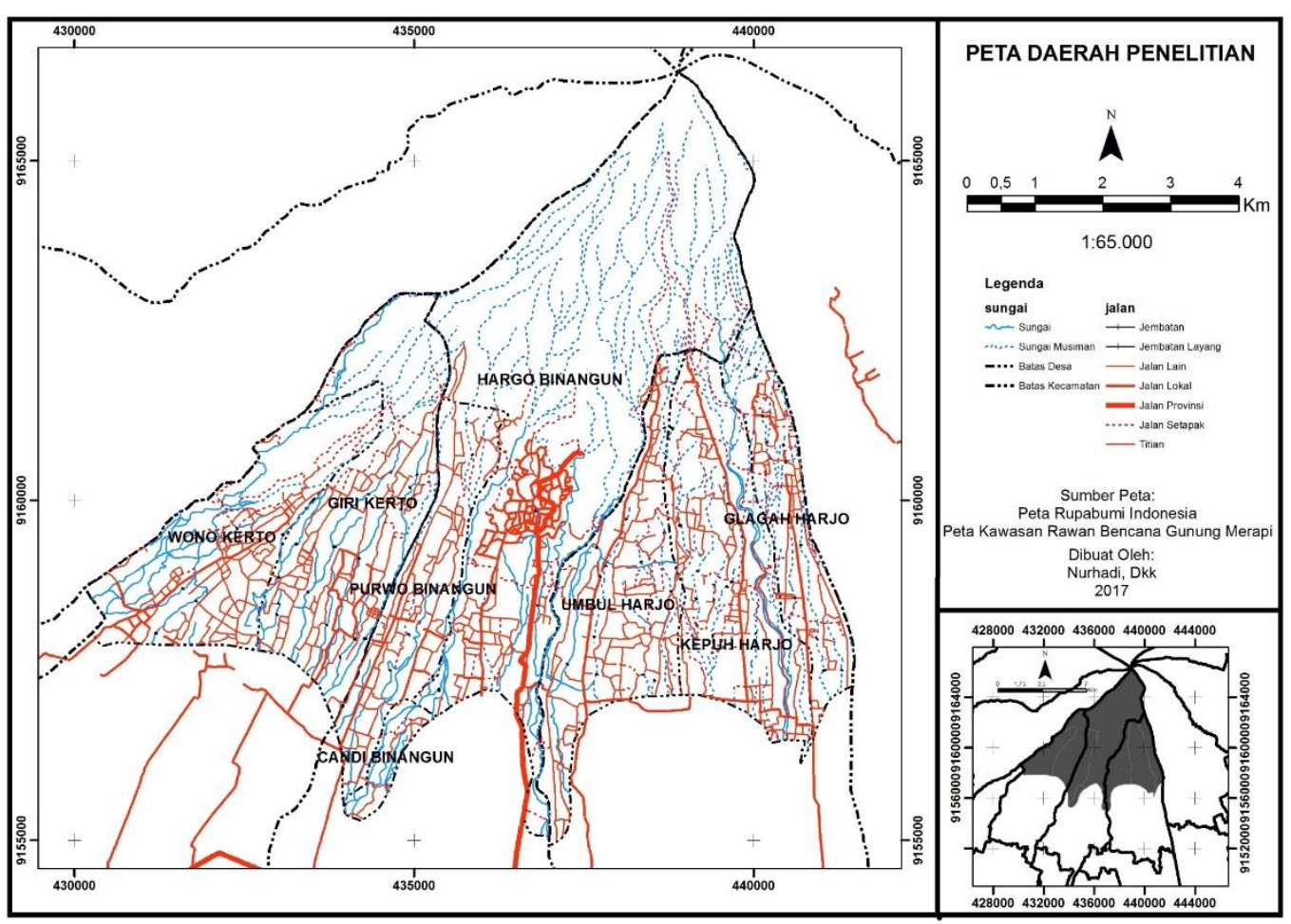

Gambar 1. Peta Administratif Daerah Penelitian

Sutikno dkk (2007) lebih lanjut menjelaskan bahwa proses endogen membentuk tubuh gunungapi, kerucut parasiter, serta keluarnya material dari kepundan baik berupa aliran piroklastik, lava, dan gas. Piroklastik dapat tertimbun di puncak gunungapi membentuk kerucut gunungapi dapat pula menuruni lereng secara gravitatif. Aliran lava dapat membeku di puncak membentuk kubah lava dan apabila terkena getaran gempa vulkanik dapat mengalami runtuhan. Endapan lava dan piroklastik dapat berkembang menjadi lahar apabila terkena air hujan sehingga mengalami penambahan berat.

Lahar merupakan fenomena yang banyak terjadi pasca bencana erupsi. Lavigne dkk (2007) menjelaskan di Gunungapi Merapi lahar umumnya berupa lahar yang dipicu oleh hujan (lahar hujan) dengan intensitas sekitar $40 \mathrm{~mm}$ selama dua jam. Kebanyakan lahar hujan terjadi selama musim penghujan dari Bulan November hingga Bulan April. Belizal dkk (2013) menjelaskan pada musim penghujan tahun 2010-2011 (Oktober 2010 - Mei 2011) terjadi 240 kali lahar, hampir pada semua lembah sungai di bawah kerucut aktif dengan jangkauan mencapai $15 \mathrm{~km}$. Lahar berdampak kepada kehidupan masyarakat serta geomorfik. Pada lereng distal lahar menyebabkan terbentuknya koridor yang luas maupun 
Karakteristik Lingkungan dan Infrastruktur Kaitannya dengan Tingkat Kesiapsiagaan di Kawasan Rawan Bencana Erups Merapi

erosi tebing sungai. Lahar merupakan fenomena yang berkaitan erat dengan aktivitas vulkanik Merapi dan telah berlangsung dalam waktu lama. Pengendapan material lahar mewarnai perkembangan geomorfologis lereng selatan Gunung Merapi. Mulyaningsih dkk (2006) menjelaskan di sisi selatan Gunung Merapi lahar mengalir melalui lembah-lembah Sungai Woro, Gendol, Opak, Kuning, Boyong, dan Krasak dalam beberapa periode. Saat ini di permukaan wilayah-wilayah tersebut masih tersingkap bongkah-bongkah lahar tahun 1930 dan 1969.

\section{Basisdata Spasial Kondisi Lingkungan dan Infrastruktur Kawasan Rawan Bencana Lereng Selatan Gunungapi Merapi}

Basisdata spasial merupakan komponen yang sangat dipelukan dalam mendukung upaya pengurangan risiko bencana. Basisdata yang terbarui akan memberikan informasi terkait dengan kerentanan dalam masyarakat dan kemampuan dalam menghadapi bencana. Informasi yang diperoleh dari basisdata tidak hanya bermanfaat bagi lembaga atau penentu kebijakan dalam pengelolaan kebencanaan, namun juga bagi masyarakat yang bertempat tinggal pada kawasan rawan bencana dan menghadapi risiko bencana. Widayani dan Tim KKN PPM UGM (2011) mencontohkan penyusunan basisdata spasial sumberdaya air melalui partisipasi masyarakat di Desa Kepuharjo Kecamatan Cangkringan, yang termasuk dalam Kawasan Rawan Bencana III Gunungapi Merapi. Dengan dibuatnya basisdata dan pemetaan masyarakat dapat mengetahui berapa banyak sumberdaya air yang dimiliki, berapa banyak yang digunakan, serta dimana saja persebarannya.

Penelitian ini telah mengidentifikasi kondisi lingkungan fisik dan infrastruktur beberapa desa yang berada di kawasan rawan bencana. Berdasarkan hasil pengumpulan data melalui observasi lapangan, studi pustaka, dan dokumentasi, disusun basisdata mengenai kondisi lingkungan fisik dan infrastruktur penunjang evakuasi pada kawasan rawan bencana II dan III lereng selatan Gunungapi Merapi khususnya mengenai kondisi geomorfologis, kondisi hidrologis, dan prasarana lingkungan. Kondisi geomorfologis yang diidentifikasi meliputi bentuklahan, morfografi dan morfometri lereng, dan proses geomorfologi. Kondisi geomorfologis merupakan faktor yang erat kaitannya dengan bahaya erupsi. Sutikno dkk (2007) menjelaskan, kondisi geomorfologis tidak terlepas dari potensi bahaya yang ada pada gunungapi merapi karena dapat diasosiasikan dengan jenis ancaman bahaya yang terdapat pada wilayah tersebut. Sebagai salah satu variabel lingkungan fisik, kondisi geomorfologis sebenarnya relatif lambat mengalami perubahan, namun demikian pasca bencana erupsi tahun 2010 dengan sifat erupsi yang berbeda dan kekuatan yang lebih besar dari beberapa peristiwa sebelumnya, diduga terdapat perubahan kondisi geomorfologis yang diakibatkan oleh erupsi (Setyawati dkk, 2013). Belizal dkk (2013) mencontohkan aliran lahar banyak berkibat terhadap kondisi geomorfik di lembah Sungai Gendol mulai dari wilayah di bawah kerucut aktif dan menyebar hingga jarak 15 km.

Daerah penelitian memiliki kondisi geomorfologis yang bervariasi. Dari aspek bentuklahan, desa-desa di daerah penelitian memiliki bentuklahan yang cukup kompleks. Walaupun memiliki bentuklahan yang bervariasi (Tabel 1) namun tidak seluruh bentuklahan di wilayah desa tersebut ditempati oleh masyarakat. Umumnya masyarakat bertempat 
tinggal pada bentuklahan kaki gunungapi dan dataran kaki gunungapi. Selain itu terdapat pula permukiman yang berada pada satuan bentuklahan lereng gunungapi, khususnya lereng bawah gunungapi. Wilayahnya permukiman yang termasuk lereng bawah gunungapi tidak terlalu luas dan beberapa diantaranya merupakan obyek wisata.

Tabel 1. Cakupan Wilayah Setiap Satuan Bentuklahan di Daerah Penelitian

\begin{tabular}{|c|c|c|c|}
\hline No & Bentuklahan & Desa & Dusun \\
\hline 1 & Kepundan & Hargobinangun & - \\
\hline 2 & Kerucut Gunungapi & Hargobinangun & - \\
\hline \multirow{5}{*}{3} & \multirow{5}{*}{ Lereng Gunungapi } & Purwobinangun & Turgo \\
\hline & & Hargobinangun & Kaliurang Timur \\
\hline & & Umbulharjo & Pelemsari, Pangukrejo \\
\hline & & Kepuharjo & Kaliadem \\
\hline & & Glagaharjo & Kalitengah Lor \\
\hline \multirow{7}{*}{4} & \multirow{7}{*}{ Kaki Gunungapi } & Wonokerto & Tunggularum \\
\hline & & Girikerto & Ngandong \\
\hline & & Purwobinangun & Kemiri \\
\hline & & Hargobinangun & $\begin{array}{l}\text { Kaliurang Barat, Ngipiksari, Boyong, } \\
\text { Banteng, Wonorejo }\end{array}$ \\
\hline & & Umbulharjo & Plosorejo, Gondang, Balong \\
\hline & & Kepuharjo & $\begin{array}{l}\text { Pagerjurang, Manggong, Kepuh, Batur, } \\
\text { Kopeng, Jambu, Petung }\end{array}$ \\
\hline & & Glagaharjo & $\begin{array}{l}\text { Glagamalang, Gading, Singlar, Srunen, } \\
\text { Kalitengah Kidul }\end{array}$ \\
\hline \multirow{5}{*}{4} & \multirow{5}{*}{$\begin{array}{l}\text { Dataran Kaki } \\
\text { Gunungapi }\end{array}$} & Wonokerto & Gondoarum, Manggungsari, Imorejo, Sempu \\
\hline & & Girikerto & Nganggring, Babadan, Kemirisawit \\
\hline & & Purwobinangun & Ngepring \\
\hline & & Hargobinangun & Sawungan \\
\hline & & Umbulharjo & Pentingsari \\
\hline
\end{tabular}

Sumber: Survei Lapangan (2017); Peta Kawasan Rawan Bencana Merapi, Badan Geologi; Peta Rupabumi Indonesia; dan Sutikno dkk (2017)

Selain bentuklahan, aspek geomorfologis lain yang penting untuk diinformasikan dalam kaitannya dengan bencana alam adalah kemiringan lereng. Daerah penelitian memiliki kemiringan lereng yang bervariasi yang berkaitan dengan bentuklahan. Sebagaimana dijelaskan oleh Verstappen (2013) gunungapi tipe strato terdiri dari beberapa segmen yang memiliki kemiringan berbeda. Masing-masing segmen tersebut dibatasi oleh tekuk lereng. Bentuklahan kerucut gunungapi memiliki kemiringan lereng paling terjal kemudian berangsur-angsur semakin landai pada bentuklahan lereng gunungapi dan kaki gunungapi. Hadi dan Setyawati (2014) menjelaskan bentuklahan kepundan dan kerucut gunungapi memiliki lereng sangat terjal, lereng gunungapi memiliki kemiringan lereng sangat terjal dan terjal, sedangkan kaki gunungapi memiliki lereng miring. Permukiman penduduk pada satuan bentuklahan kaki gunungapi memilki kemiringan lereng bervariasi antara $6 \%$ hingga $20 \%$. Bentuklereng umumnya lurus, namun di beberapa tempat terdapat lereng cembung dan cekung. Proses geomorfologi yang berlangsung terdiri dari deposisi material vulkanik, pelapukan, serta erosi. Proses geomorfologi lainnya adalah pelapukan material hasil erupsi masa lampau serta erosi terutama berupa erosi lembar dan erosi alur. 
Basisdata spasial kondisi hidrologis yang disusun dalam penelitian ini meliputi aspek kualitas air dan kuantitas air sungai. Kualitas air meliputi suhu air, pH air, dan daya hantar listrik. Suhu air di merupakan variabel yang perlu diinformasikan karena (1) berkaitan dengan dissolved oxygen, yaitu pada air hangat kemampuan menahan oksigen lebih sedikit, (2) sebagai faktor pengendali laju reaksi kimia yang terjadi di dalam sungai. Daya hantar listrik disebut juga electric conductivity yaitu kemampuan air untuk menghantarkan arus listrik yang merupakan fungsi dari konsentrasi larutan. Sungai biasanya memiliki konduktivitas antara 10 hingga $1000 \mu \mathrm{S} / \mathrm{cm}$. pH dikenal sebagai derajat keasaman atau kebasaan merupakan variabel air yang penting karena menentukan mutu air. Di perairan alami tingkat $\mathrm{pH}$ sangat bervariasi (Davie, 2008). Adapun kuantitas air ditunjukkan oleh debit aliran.

Kondisi hidrologis yang dikaji untuk penyusunan basisdata dalam penelitian ini adalah kualitas dan kuantitas air pada sungai. Sungai digunakan sebagai unit analisis karena mendapat imbuhan air dari mataair dan di daerah penelitian kebanyakan sungai bersifat perennial walaupun alirannya sangat kecil. Selain itu sungai dapat bermanfaat sebagai alternatif sumber air selain potensi sumber air utama dari mataair. Masyarakat pada kawasan rawan bencana III dan II di daerah penelitian menggunakan sumber air dari mataair yang disalurkan ke permukiman dengan menggunkan pipa. Dalam situasi darurat bencana penyaluran sumber air dapat terhambat apabila pipa penyalur mengalami kerusakan. Dengan demikian aliran sungai yang bersumber dari mataair dapat digunakan sebagai alternatif sumber air dengan catatan harus dilakukan kajian terlebih dahulu mengenai kualitas dan kuantitasnya. Dalam penelitian ini variabel kualitas air yang diidentifikasi adalah suhu air, $\mathrm{pH}$, dan daya hantar listrik (Tabel 2).

Tabel 2. Kualitas dan Kuantitas Air Sungai di Daerah Penelitian

\begin{tabular}{|c|c|c|c|c|c|}
\hline No & $\begin{array}{l}\text { Kondisi Hidrologis } \\
\text { Nama Sungai }\end{array}$ & $\begin{array}{l}\text { Suhu Air } \\
\left({ }^{0} \mathrm{C}\right)\end{array}$ & $\mathrm{pH}$ & $\begin{array}{c}\mathrm{DHL} \\
(\mu \mathrm{S} / \mathrm{cm})\end{array}$ & $\begin{array}{c}\text { Debit Sungai } \\
\left(\mathrm{m}^{3} / \text { detik) }\right.\end{array}$ \\
\hline 1 & Sungai Krasak & 29,31 & 7,82 & 356 & 0,37 \\
\hline 2 & Sungai Boyong & 26,00 & 7,91 & 211 & 5,23 \\
\hline 3 & Sungai Kuning & 24,77 & 7,95 & 212 & 0,92 \\
\hline 4 & Sungai Sempor & 23,24 & 7,97 & 190 & 0,25 \\
\hline 5 & Sungai Denggung & 23,80 & 7,84 & 132 & 0,12 \\
\hline
\end{tabular}

Sumber: Data Lapangan (2017)

Penyusunan basisdata pada aspek keterjangkauan dan prasarana perhubungan meliputi aksesibilitas dalam menjangkau suatu wilayah, kondisi jalan baik jalan utama maupun jalan lokal di dalam permukiman, serta material yang digunakan dalam membangun jalan. Desa Wonokerto secara umum wilayah permukimannya memiliki aksesibilitas yang baik. Permukiman pada kawasan rawan bencana II seluruhnya dapat dijangkau dengan jalan aspal sebagai akses utama. Namun demikian, jalan aspal tersebut relatif sempit dan terdapat kerusakan minor di sekitar wilayah Tlatar. Secara umum aksesibilitas di desa ini termasuk baik. Jalan lokal dalam permukiman berupa aspal seperti dijumpai di wilayah permukiman Sempu, cor blok seperti dijumpai di wilayah Tlatar dan Gondoarum, maupun kombinasi keduanya seperti dijumpai di wilayah Tunggularum. 
Aksesibilitas di Desa Girikerto relatif bervariasi. Wilayah yang termasuk dalam kawasan rawan bencana II dapat dijangkau dengan jalan aspal yang relatif lebar seperti dijumpai di wilayah Nganggring, Tegalpanggung, dan Kemirikebo. Namun demikian pada kawasan rawan bencana III seperti di Ngandong dan Tritis aksesibilitas lebih terbatas karena jalan lebih sempit dan berkelok melintasi kebun campuran yang sangat minim penerangan. Wilayah ini masih dapat dijangkau dengan jalan beraspal namun hanya muat untuk satu mobil minibus. Akses jalan dalam permukiman sudah sangat baik berupa aspal dikombinasikan dengan cor blok atau paving blok seperti di wilayah Kemirikebo, Kuncen, Nangsri, Tegalpanggung, dan Nyangkring.

Desa Purwobinangun memiliki aksesibilitas yang cukup baik hingga menjangkau kawasan rawan bencana III di wilayah Turgo. Aksesibilitas yang baik juga tidak terlepas dari pengembangan wisata dimana kawasan Turgo relatif dekat dengan kawasan wisata Kaliurang. Walaupun tidak dikelola dengan baik seperti Kawasan Wisata Kaliurang, Kawasan Turgo seringkali juga menjadi tujuan wisata baik rekreasi maupun wisata spiritual. Akses jalan beraspal yang cukup lebar telah menjangkau hingga wilayah Turgo. Kondisi jalan lokal di wilayah permukiman juga cukup baik terutama berupa cor blok seperti dijumpai di wilayah Candi dan Ngepring. Desa Umbulharjo memiliki aksesibilitas yang sangat baik karena memiliki kawasan wisata Kaliurang yang telah lama berkembang. Jalur wisata Kaliurang merupkan akses utama dengan kualitas material jalan yang sangat baik dan dapat dilintasi kendaraan ukuran besar. Aksesibilitas yang baik sangat mendukung proses evakuasi. Aksesibilitas jalan lokal secara umum juga cukup baik dengan bahan kombinasi antara aspal dan cor blok seperti dijumpai di wilayah Boyong, Tanen, dan Banteng.

Aksesibilitas baik yang ditunjang oleh jalur wisata juga terdapat di Desa Umbulharjo yaitu wisata lava tour yang berkembang pasca bencana erupsi tahun 2010. Pada peristiwa erupsi tahun 2010 wilayah ini sebenarnya termasuk wilayah yang paling banyak terkena dampak erupsi. Badan Geologi dalam Peta Kawasan Rawan Bencana Gunung Merapi dan Area Terdampak Letusan Tahun 2010 menjelaskan wilayah ini merupakan area terdampak langsung, yaitu area yang terlanda awan panas yang menimbulkan korban jiwa, kerusakan permukiman, infrastruktur dan vegetasi yang terbakar. Wilayah ini banyak mengalami kerusakan namun aksesibilitas saat ini cukup baik karena faktor wisata. Aksesibilitas di daerah bekas permukiman yang terlanda awan panas mengalami banyak kerusakan sehingga akses sangat terbatas namun wilayah ini tidak lagi ditempati untuk permukiman.

Desa Kepuharjo secara umum memiliki aksesibilitas yang baik dengan jalan aspal yang dapat dilintasi kendaraan besar. Beberapa lokasi aksesibilitas terhambat karena kerusakan jalan yang diperbaiki dengan membangun jalan cor blok seperti dijumpai di wilayah Kopeng. Wilayah ini juga termasuk area terdampak letusan langsung yang terlanda awan panas sehingga banyak mengalami kerusakan. beberapa akses jalan yang tergambar pada peta sebelum tahun 2010 sulit diidentifikasi pada saat ini. Wilayah Kaliadem dan sekitarnya pada saat ini memiliki aksesibilitas yang relatif buruk. Desa Glagaharjo memiliki aksesibilitas yang kurang baik bila dibandingkan dengan desa lain yang memiliki kawasan rawan bencana II dan III. Pada tahun 2017 akses utama menuju wilayah desa ini mengalami kerusakan sehingga menghambat mobilitas dalam penanganan bencana. 


\section{Pengaruh Kondisi Lingkungan Fisik dan Infrastruktur Terhadap Kesiapsiagaan dalam Menghadapi Bencana}

Kondisi lingkungan fisik yang dikaji dalam penelitian ini meliputi kondisi geologis, geomorfologis, dan hidrologis. Kondisi geologis berupa litologi batuan penyusun. Kondisi geomorfologis meliputi bentuklahan, ketinggian tempat, kemiringan lereng, proses geomorfologi, jarak dari lembah sungai besar, serta jarak dari kepundan gunungapi. Kondisi hidrologis meliputi kualitas sumber air permukaan khususnya suhu air, pH air, dan daya hantar listrik (DHL) serta kuantitas air yang ditunjukkan oleh debit aliran sungai.

Wilayah Desa Wonokerto secara geomorfologis memiliki kondisi yang beragam antara lain (1) bentuklahan kaki dan dataran kaki gunungapi, (2) ketinggian tempat berkisar antara 600 mdpal di wilayah permukiman Sempu hingga 750 mdpal di wilayah Gondoarum, (3) permukiman umumnya jauh dari lembah sungai utama, jarak terdekat permukiman ke lembah sungai adalah 300 meter di wilayah Tlatar, (4) terdapat permukiman yang terletak pada jarak $9 \mathrm{~km}$ dari pusat erupsi yaitu di Tunggularum, namun umumnya permukiman terletak pada jarak 10 hingga $12 \mathrm{~km}$, (5) kelas kemiringan lereng bervariasi antara landai hingga miring. Wilayah Desa Wonokerto dilintasi oleh Sungai Krasak yang merupakan salah satu sungai berhulu di sekitar kerucut gunungapi. Lembah Sungai Krasak cukup lebar namun debit aliran sungainya sangat kecil yaitu hanya sekitar $0,37 \mathrm{~m}^{3} /$ detik. Hasil pengukuran kualitas air Sungai Krasak menunjukkan suhu air $23,91^{\circ} \mathrm{C}, \mathrm{pH} 7,82$, dan daya hantar listrik (DHL) $356 \mu \mathrm{S} / \mathrm{cm}$. Selain Sungai Krasak terdapat sungai lain yang bersifat perennial yaitu Sungai Sempor. Debit Sungai Sempor pada awal musim penghujan di Bulan

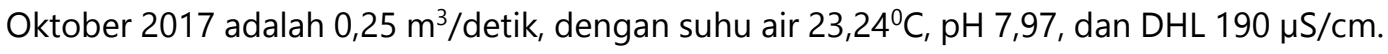

Berbeda dengan Desa Wonokerto, Desa Girikerto tidak dilintasi oleh lembah sungai besar yang mengalirkan material hasil erupsi. Namun demikian wilayah ini juga memiliki potensi bahaya dari aspek lingkungan fisik lain terutama geomorfologis. Desa Girikerto tersusun oleh endapan piroklastik dan lahar yang merupakan material Gunungapi Merapi muda. Karakteristik geomorfologis Desa Girikerto antara lain: (1) bentuklahan kaki dan dataran kaki gunungapi, (2) ketinggian tempat antara 590 mdpal di wilayah Kuncen hingga 900 mdpal di wilayah Tritis, (3) seluruh permukiman terletak pada jarak $>500$ meter dari sungai, (4) jarak terdekat antara permukiman dengan pusat erupsi adalah $7 \mathrm{~km}$ di wilayah Tritis sedangkan jarak terjauh adalah $11 \mathrm{~km}$ di Kuncen, (5) kelas kemiringan lereng bervariasi antara landai hingga Agak Terjal.

Desa Purwobinangun juga tersusun dari endapan piroklastik dan lahar. Di wilayah Bukit Turgo terdapat material penyusun yang berbeda yaitu endapan gunungapi Merapi Tua. Secara geomorfologis Desa Purwobinangun memiliki karakteristik (1) bentuklahan beragam yaitu mulai dari lereng gunungapi hingga dataran kaki gunungapi, (2) ketinggian tempat terendah di wilayah permukiman Candi yaitu $566 \mathrm{mdpal}$ dan di wilayah Turgo yaitu 1.000 mdpal, (3) kemiringan lereng bervariasi antara landai hingga agak terjal (4) jarak dari sungai besar berkisar antara 100 meter hingga 500 meter (5) jarak terdekat antara permukiman dengan pusat erupsi adalah $6 \mathrm{~km}$ di wilayah Turgo dan jarak terjauh adalah $11 \mathrm{~km}$ di candi. Wilayah Purwobinangun dilintasi oleh Sungai Boyong yang berhulu dari wilaayah kerucut gunungapi. Sungai Boyong memiliki lembah yang lebar dan dalam. Debit 
aliran sungai ini 5,23 $\mathrm{m}^{3} /$ detik dengan suhu air 26,00 ${ }^{\circ} \mathrm{C}, \mathrm{pH}$ 7,91, dan DHL $211356 \mu \mathrm{S} / \mathrm{cm}$. Sungai Boyong membatasi Desa Purwobinangun dengan Hargobinangun.

Desa Hargobinangun merupakan desa dengan material penyusun dan bentuklahan yang paling bervariasi. Desa Hargobinangun juga dilintasi oleh Sungai Besar. Selain Sungai Boyong yang terletak di batas barat desa ini, di batas timur terdapat Sungai Kuning yang juga memiliki lembah lebar dan dalam. Sungai Kuning memiliki debit $0,92 \mathrm{~m}^{3} /$ detik dengan suhu $24,77^{\circ} \mathrm{C}, \mathrm{pH} 7,95$, dan DHL 212. Secara geomorfologis Desa Hargobinangun memiliki kondisi: (1) bentuklahan beragam terdiri dari kepundan, kerucut gunungapi, lereng gunungapi, kaki gunungapi, dan dataran kaki gunungapi. Permukiman penduduk terdapat pada lereng bawah gunungapi di Kawasan Wisata Kaliurang, serta kaki gunungapi dan dataran kaki gunungapi. (2) ketinggian tempat terendah yang disampel dalam penelitian ini adalah 600 mdpal di wilayah Banteng dan tertinggi 700 mdpal di wilayah Boyong, (3) kemiringan lereng bervariasi antara landai hingga terjal (4) karena dibatasi oleh Sungai Besar di kedua sisi maka jarak antara permukiman dengan sungai besar berkisar relatif dekat yaitu 100 hingga 400 meter (5) jarak dari pusat erupsi umumnya $9 \mathrm{~km}$.

Desa Umbulharjo berbatasan dengan Desa Hargobinangun di lembah Sungai Kuning. Desa Umbulharjo bersama dengan Kepuharjo dan Glagaharjo merupakan wilayah yang terdampak langsung oleh erupsi Gunungapi Merapi pada tahun 2010. Desa Umbulharjo juga memiliki kondisi material penyusun, bentuklahan, dan kemiringan lereng yang kompleks. Ketinggian tempat yang disampel bervariasi antara $679 \mathrm{mdpal}$ di wilayah Balong hingga 1100 mdpal di wilayah Kinahrejo yang sekarang dikembangkan sebagai Obyek Wisata Lava Tour Merapi. Kinahrejo relatif dekat dari puncak dengan jarak 5 km, sedangkan Balong terletak pada jarak $9 \mathrm{~km}$. Permukiman di Desa Umbulharjo umumnya terletak agak jauh dari lembah sungai besar dengan jarak sekitar 400 meter.

Desa Kepuharjo terletak di sebelah timur Desa Umbulharjo. Wilayah ini memiliki ketinggian tempat $650 \mathrm{mdpal}$ hingga $776 \mathrm{mdpal}$. Jarak permukiman dari pusat erupsi pada kawasan rawan bencana umumnya rata-rata km. Wilayah Desa Kepuharjo dilintasi oleh Sungai Opak dan Sungai Gendol. Sungai ini tidak perennial tetapi memiliki potensi bahaya yang sangat besar karena mengalirkan material hasil erupsi dari kepundan gunungapi. Pada erupsi 2010 Sungai Gendol dilintasi oleh awan panas yang menyebabkan kerusakan besar. Lembah Sungai Gendol membatasi Desa Kepuharjo dengan Desa Glagaharjo. Karakteristik fisik kedua desa ini relatif sama sehingga memiliki potensi bahaya yang sama pula.

Disisi lain desa-desa yang wilayahnya termasuk dalam kawasan rawan bencana II dan III telah mengembangkan sistem pengelolaan kebencanaan yang baik sehingga memiliki tingkat kesiapsiagaan yang tinggi. Sistem pengelolaan kebencanaan semakin berkembang pesat pasca bencana erupsi tahun 2010 karena wilayah lereng selatan Gunungapi Merapi banyak terkena dampak pada saat bencana erupsi. Badan Geologi melalui Peta Kawasan Rawan Bencana Gunung Merapi dan Area Terdampak Letusan 2010 menunjukkan area terdampak letusan 2010 meliputi kawasan rawan bencana III lereng selatan hingga baratdaya, kecuali Kawasan Wisata Kaliurang yang terlindungi oleh keberadaan Bukit Turgo dan Plawangan. Diantara area terdampak tersebut terdapat area terdampak langsung yaitu di wilayah sekitar Sungai Gendol meliputi Desa Umbulharjo, Kepuharjo, dan Glagaharjo. 
Karakteristik Lingkungan dan Infrastruktur Kaitannya dengan Tingkat Kesiapsiagaan di Kawasan Rawan Bencana Erupsi Merapi

Tingkat kesiapsiagaan tinggi ditunjukkan oleh upaya pengelolaan kebencanaan yang telah dilakukan oleh pemerintah setempat bersama masyarakat. Terdapat beberapa indikator yaitu: (1) telah melakukan penilaian bahaya dan kerentanan berdasarkan rencana pengurangan risiko bencana pasca erupsi dan data kependudukan mutakhir, (2) memahami dan dapat melakukan prediksi dampak erupsi terhadap fasilitas, infrastuktur, dan populasi, (3) berbagi data dan informasi dengan stakeholder lain, (4) membentuk pengelola untuk meningkatkan kesiapsiagaan, (5) ada pembagian peran dan prosedur dalam manajemen bencana, (6) melakukan pelatihan, simulasi, dan mengedukasi masyarakat, (7) mengembangkan rencana evakuasi dan kesepakatan mutual terkait bencana dengan pihak lain, (8) ada partisipasi dalam perencanaan penanggulangan bencana dan mempersiapkan penanganan bencana serta pemulihan, (9) menyiapkan berbagai keperluan terkait evakuasi, dan (10) ada inisiatif untuk mendukung penanganan bencana.

Pasca bencana erupsi tahun 2010 lembaga pengelolaan kebencanaan di tingkat desa melakukan penilaian bahaya dan kerentanan pada masa mendatang. Penilaian didasarkan pada rencana tindakan pengurangan risiko bencana serta kondisi terbaru khususnya kependudukan. Namun demikian belum semua desa di daerah penelitian melakukan penghitungan dan belum semua penghitungan berlangsung secara efektif. Desa-desa yang melakukan penilaian terutama yang terdampak langsung oleh letusan tahun 2010. Dengan penilaian bahaya dan kerentanan tersebut masyarakat melalui lembaga pengelolaan bencana tingkat desa memahami dan dapat mengidentifikasi potensi dampak erupsi pada fasilitas, infrastruktur, dan populasi, di wilayahnya.

Seluruh desa di daerah penelitian telah mengembangkan lembaga pengelolaan bencana. Dengan adanya lembaga tersebut koordinasi dalam perencanaan dan pelaksanaan penanggulangan bencana menjadi lebih mudah dan lancar, baik koordinasi antar anggota masyarakat maupun dengan lembaga pemerintah yang terkait dengan penanggulangan bencana. Lembaga pengelolaan bencana tingkat desa memiliki nama yang spesifik seperti FPRB / Forum Pengurangan Risiko Bencana (Desa Girikerto), LABA / Linmas Anggota Peduli Bencana (Desa Purwobinangun), atau secara umum disebut sebagai OPRB / Organisasi Pengurangan Risiko Bencana maupun Unit Pelaksana Penanggulangan Bencana. Lembaga pengelolaan bencana di sebagian desa dikelola secara rangkap jabatan oleh staff desa, di beberapa desa lainnya memiliki staf sendiri secara lebih luas dengan melibatkan relawan. Lembaga pengelolaan bencana desa menyediakan informasi untuk stakeholder lain khususnya BPBD.

Dalam upaya meningkatkan kesiapsiagaan, desa-desa di daerah penelitian yang wilayahnya termasuk dalam kawasan rawan bencana II dan III menyelenggarakan kerjasama dengan desa lain di luar kawasan rawan bencana. Sebagai contoh Desa Purwobinangun menjalin kerjasama desa mitra dengan Desa Donoharjo, Desa Hargobinangun bekerjasama dengan Desa Harjobinangun, Desa Umbulharjo bekerjasama dengan desa Wukirsari, serta Desa Kepuharjo yang menjalin kerjasama dengan Desa Wukirsari, Bimomartani, dan Maguwoharjo. Namun demikian walaupun pengelolaan kebencanaan telah dilakukan dengan baik sehingga mengindikasikan tingkat kesiapsiagaan yang tinggi, namun masih terdapat beberapa aspek kesiapsiagaan yang perlu ditingkatkan antara lain kemampuan 
untuk mengidentifikasi sumberdaya yang belum dikenal sebelumnya, kemampuan melindungi sumberdaya yang kritis, memanfaatkan sumberdaya dalam situasi darurat dan memastikan bahwa sumberdaya dapat dimanfaatkan selama bencana, serta asuransi.

Lembaga pengelolaan bencana tingkat desa secara umum telah banyak berperan dalam penanganan bencana di masing-masing wilayah. Dengan adanya lembaga pengelolaan bencana dapat ditetapkan standar tertentu dalam penanganan bencana di suatu desa. Walaupun telah ada standar tertentu di wilayah desa namun tidak menutup kemungkinan adanya perbedaan kesiapsiagaan antar wilayah permukiman yang disebabkan oleh kemampuan masyarakat dalam beradaptasi dengan potensi bencana, kemauan untuk berperan aktif, serta upaya yang dilakukan untuk membantu penanganan bencana yang berbeda-beda antar wilayah permukiman. Wilayah permukiman yang menghadapi potensi bahaya lebih besar umumnya mendorong masyarakat untuk berperan lebih aktif dalam mendukung penanganan bencana. Sebagai contoh masyarakat di Dusun Tunggularum Desa Wonokerto dan Dusun Tritis Desa Girikerto membangun pos keamanan lingkungan dalam bentuk menara pengawas untuk pengamatan kondisi Gunung Merapi.

Untuk menunjukkan pengaruh kondisi lingkungan fisik terhadap kesiapsiagaan dalam menghadapi bencana serta melihat kecenderungannya, digunakan analisis regresi linier sederhana dengan terlebih dahulu melakukan penilaian (skoring) aspek kondisi lingkungan fisik dan aspek kesiapsiagaan. Terdapat 20 variabel pada aspek lingkungan fisik yang berkaitan dengan potensi bahaya. Penghitungan dilakukan pada 27 wilayah permukiman masyarakat yang digunakan sebagai sampel. Nilai terendah yang diberikan adalah 20 dan nilai tertinggi 70. Sementara itu dalam penilaian aspek kesiapsiagaan terdapat 35 variabel dengan rentang nilai yang diberikan antara 35 hingga 105. Hasil analisis menunjukkan adanya hubungan yang linear dan positif dengan nilai $\mathrm{R}^{2}$ sebesar 0,517 . Hasil ini menunjukkan kondisi lingkungan fisik suatu wilayah merupakan salah satu faktor yang mempengaruhi masyarakat untuk meningkatkan kesiapsiagaan dalam menghadapi bencana. Semakin tinggi nilai kondisi lingkungan fisik suatu wilayah yang berarti semakin tinggi potensi bahaya di wilayah tersebut ternyata cenderung meningkatkan kesiapsiagaan yang ditunjukkan oleh semakin tingginya nilai kesiapsiagaan yang diperoleh. Namun demikian pengaruh ini belum cukup signifikan.

Penyebab pengaruh yang belum signifikan adalah karena penelitian ini terbatas pada tujuan untuk mengukur tingkat kesiapsiagaan masyarakat melalui organisasi pengurangan risiko bencana (OPRB). Sutton dan Tierney (2006) menjelaskan pengukuran kesiapsiagaan dapat dilakukan dalam unit keluarga (household), perusahaan (business), maupun masyarakat dan organisasi (communities and organization). Di daerah penelitian OPRB dikelola dalam skala desa, sedangkan potensi bahaya yang dihadapi antar wilayah permukiman berbeda-beda akibat perbedaan kondisi lingkungan fisik dan infrastruktur. Oleh karena OPRB dikelola pada tingkat desa, maka banyak aspek kesiapsiagaan yang ditangani berdasarkan standar di tingkat desa sehingga memungkinkan adanya kesamaan antar wilayah permukiman di desa yang sama. Adanya perbedaan antar wilayah permukiman adalah sebagai hasil improvisasi masing-masing wilayah dalam meningkatkan kesiapsiagaan seperti membangun menara pengawas dan perbaikan infrastruktur 
Karakteristik Lingkungan dan Infrastruktur Kaitannya dengan Tingkat Kesiapsiagaan di Kawasan Rawan Bencana Erupsi Merapi

lingkungan. Lebih lanjut masih perlu analisis untuk menemukan faktor lain yang turut mempengaruhi pengaruh karakteristik lingkungan fisik terhadap tingkat kesiapsiagaan.

\section{Perbedaan Kondisi Lingkungan Fisik Permukiman dan Infrastruktur Antar Wilayah dalam Mempengaruhi Tingkat Kesiapsiagaan}

Secara umum permukiman masyarakat dalam kaitannya dengan potensi bahaya yang dihadapi dapat dibedakan menjadi dua kelompok yaitu permukiman dengan kondisi fisik yang potensial terhadap bahaya dan permukiman dengan kondisi fisik yang relatif tidak berbahaya. Kondisi lingkungan fisik yang mempengaruhi potensi bahaya terdiri dari faktor geologis, geomorfologis dan hidrologis sebagaimana telah dijelaskan pada bagian sebelumnya. Permukiman yang memiliki potensi bahaya lebih tinggi ditunjukkan oleh skor yang lebih besar. Dalam penelitian ini kelompok pertama merupakan permukiman yang memperoleh skor lingkungan fisik 28 hingga 36 meliputi Imorejo, Tegalpanggung, Sempu, Ngelodadi, Kuncen, Kemirikebo, Candi, Tanen, Tlatar, Gondoarum, Nganggring, Boyong, dan Balong. Adapun kelompok kedua memiliki skor 37 hingga 51 antara lain Ngepring, Banteng, Tunggularum, Pagerjurang, Banjarsari, Gondang, Kopeng, Batur, Ngacar, Glagahmalang, Ngandong, Tritis, dan Turgo. Kinahrejo tidak dimasukkan dalam salah satu kelompok karena merupakan wilayah yang dikembangkan sebagai obyek wisata.

Wilayah permukiman pada kelompok pertama potensi bahaya yang relatif rendah karena faktor jarak yang jauh dari pusat erupsi, kemiringan lereng rendah, prasarana yang relatif baik, serta kondisi hidrologis yang dapat dimanfaatkan sebagai sumberdaya pendukung dalam situasi darurat bencana. Permukiman di Desa Wonokerto dan Girikerto khususnya yang berada pada kawasan rawan bencana II mendominasi kelompok ini. Sementara itu kelompok kedua wilayah permukimannya memiliki kecenderungan potensi bahaya lebih tinggi karena faktor jarak yang lebih dekat dari pusat erupsi, kemiringan lereng lebih terjal, fungsi hidrologis sebagai sumberdaya pendukung tidak ada. Permukiman di Desa Umbulharjo, Kepuharjo, dan Glagaharjo yang pada saat erupsi tahun 2010 terkena dampak langsung, mendominasi kelompok ini.

Diantara 20 variabel faktor kondisi lingkungan fisik dan infrastruktur yang berpengaruh terhadap kesiapsiagaan masyarakat, variabel yang paling menunjukkan perbedaan diantara kedua kelompok sehingga mempengaruhi kesiapsiagaan adalah faktor ketinggian tempat, jarak dari pusat erupsi, jarak dari lembah sungai utama, serta kondisi hidrologis. Sebaliknya variabel seperti bentuklahan, proses geomorfologi, aksesibilitas, serta fasilitas air bersih dan listrik cenderung tidak berkaitan dengan perbedaan tersebut. Hal ini disebabkan karena variabel bentuklahan, proses geomorfologi, aksesibilitas, serta fasilitas air bersih dan listrik bersifat lebih umum, lebih luas, sehingga ada memungkinkan adanya kesamaan antar wilayah permukiman, sementara kondisi variabel lainnya berbeda.

Ketinggian tempat menurut Sutikno dkk (2007) sebagaimana telah dijelaskan pada bagian sebelumnya, berkaitan dengan jenis bahaya pada suatu wilayah. Wilayah yang menghadapi jenis bahaya lebih bervariasi memiliki ancaman yang berbeda dengan wilayah yang menghadapi bahaya lebih sedikit. Masyarakat yang bertempat tinggal pada daerah yang terancam bahaya lebih banyak akan mengupayakan tindakan tertentu sebagai bentuk 
respon terhadap ancaman bahaya tersebut. Ketinggian tempat biasanya juga berkaitan dengan jarak dari pusat erupsi semakin tinggi tempat maka semakin dekat pula jaraknya dengan pusat erupsi. karena adanya kombinasi dari kedua faktor ini maka keduanya akan menghasilkan nilai yang sangat menentukan skor akhir yang menunjukkan potensi bahaya.

Faktor hidrologis juga sangat menentukan perbedaan. Hasil pengamatan di lapangan menunjukkan bahwa kondisi hidrologis di daerah penelitian cenderung menghasilkan dua kelompok yang saling bertolak belakang yaitu antara wilayah yang memiliki potensi sumberdaya air permukaan dan yang tidak memiliki potensi sumberdaya air permukaan. Pada daerah yang memiliki potensi sumberdaya air permukaan, karakteristik kualitas dan kuantitas airnya relatif sama. Debit aliran pada sungai-sungai yang bersifat perennial relatif sama. Suhu air juga relatif sama yang semuanya menunjukkan perbedaan kurang dari tiga terhadap suhu udara rata-rata. $\mathrm{pH}$ air juga tidak menunjukkan variasi, yaitu semua sampel menunjukkan nilai 7. Hanya nilai daya hantar listrik yang menunjukkan adanya variasi namun tidak berbeda secara signifikan. Karena potensi sumberdaya air permukaan relatif tidak ada perbedaan, maka variabel ini menyumbangkan nilai yang sama yaitu rendah dalam menentukan potensi bahaya. hal ini karena sumberdaya air dapat dimanfaatkan sebagai sumberdaya alternatif dalam kondisi darurat bencana. Dengan demikian daerah yang memiliki potensi sumberdaya air permukaan mempunyai persediaan kritis apabila mataair sebagai sumber air utama terhambat distribusinya akibat kerusakan jaringan pipa penyalur pada saat terjadi bencana.

Sebaliknya, daerah yang tidak memiliki potensi sumberdaya air permukaan yang bersifat perennial akan cenderung memiliki nilai bahaya yang tinggi karena ketiadaan sumberdaya pendukung dalam situasi daruarat bencana. Daerah yang tidak memiliki potensi sumberdaya air permukaan cukup banyak di daerah penelitian terutama di daerah yang terdampak langsung oleh erupsi tahun 2010. Selanjutnya perbedaan kondisi lingkungan ini mempengaruhi masyarakat yang menempatinya untuk beradaptasi sehingga menghasilkan nilai kesiapsiagaan yang berbeda pula. Terbukti berdasarkan hasil skoring Desa Wonokerto dan Girikerto yang tidak terkena dampak erupsi langsung cenderung memiliki skor kesiapsiagaan lebih rendah dibandingkan Desa Umbulharjo, Kepuharjo, dan Glagaharjo yang terkena dampak erupsi langsung.

\section{SIMPULAN}

Erupsi Gunungapi Merapi tahun 2010 telah menyebabkan perubahan kondisi fisik maupun sosial masyarakat yang bertempat tinggal di kawasan rawan bencana. Dalam pengelolaan kebencanaan yang berkesinambungan di masa mendatang keterbaruan data dan informasi sangat diperlukan, salah satunya dengan menyusun basisdata spasial. Kondisi lingkungan fisik pada wilayah permukiman merupakan salah satu faktor yang mempengaruhi kesiapsiagaan. Wilayah permukiman yang karena faktor geologis, geomorfologis, dan hidrologisnya cenderung memiliki potensi bahaya tinggi akan mendorong masyarakat yang bertempat tinggal di wilayah tersebut untuk beradaptasi dengan meningkatkan kesiapsiagaan. Namun demikian pengaruhnya tidak signifikan karena kesiapsiagaan berkaitan dengan pengelolaan bencana dengan standar tertentu 
pada tingkat desa, sedangkan kondisi lingkungan fisik sangat bervariasi antar wilayah permukiman. Perbedaan perbedaan kondisi lingkungan fisik berpengaruh terhadap perbedaan kesiapsiagaan. Faktor yang berpengaruh terutama adalah ketinggian tempat, jarak dari pusat erupsi, jarak dari lembah sungai utama, dan kondisi hidrologis.

\section{UCAPAN TERIMA KASIH}

Penelitian ini dibiayai dengan Dana DIPA FIS UNY tahun 2017 melalui Hibah Penelitian Kelompok FIS UNY. Penulis mengucapkan terima kasih kepada FIS UNY yang telah membiayai penelitian ini serta berbagai pihak yang telah membantu dalam proses penelitian sehingga penelitian ini dapat terlaksana dengan baik.

\section{DAFTAR PUSTAKA}

Belizal, E.D., Lavigne, F., Hadmoko, D.S., Degeai, J-P. Dipayana, G.A., Mutaqin, B.W., Marfai, M.A., Coquet, M., Mauff, B.L., Robin, A.K., Vidal, C., Cholik, N., dan Aisyah, N. 2013. RainTriggered Lahars Flowing the 2010 Eruption of Merapi Volcano, Indonesia: A Major Risk. Journal of Volcanology an Geothermal Research 261 (2013): 330-347.

BPS. 2017. Hasil Sensus Penduduk Tahun 2010. dalam www.sp2010.bps.go.id diakes pada tanggal 20 Maret 2017.

Davie, T. 2008. Fundamentals of Hydrology Second Edition. London: Routledge.

Hadi, B.S. dan Setyawati, S. 2014. Penyusunan Sistem Informasi Bahaya dan Risiko Bencana Erupsi Gunungapi Merapi Pasca Erupsi 2010. Laporan Penelitian Hibah Bersaing Tahun Kedua. LPPM UNY.

Setyawati, S., Hadi, B.S., dan Ashari, A. 2013. Pengambangan Sistem Informasi Bahaya erupsi untuk Pengelolaan Kebencanaan di Lereng Selatan Gunungapi Merapi. Majalah Geografi Indonesia 27 (2): 138-148.

Lavigne, F., Thouret, J-C., Hadmoko, D.S., Sukatja, C.B. 2007. Lahars in Java: Initiations, Dynamics, Hazards Assessment and Deposition Process. Forum Geografi 21 (1): 17-32.

Mulyaningsih, S. Sampurno., Zaim, Y., Puradimaja, D.J., Bronto, S., dan Siregar, D.A. 2006. Perkembangan Geologi pada Kuarter Awal sampai Masa Sejarah di Dataran Yogyakarta. Jurnal Geologi Indonesia 1 (2): 103-113.

Simoen, S. 2001. Sistem Akuifer di Lereng Gunungapi Merapi Bagian Timur dan Tenggara. Majalah Geografi Indonesia 15 (1): 1-16

Sudibyakto. 2011. Risiko Bila Merapi Meletus. dalam Manajemen Bencana Indonesia Kemana? Yogyakarta: Gadjah Mada University Press.

Sutawidjaja, I.S. 2013. Directed Volcanic Blast as a Tragedy of October 26th, 2010 at Merapi Volcano Central Java. Indonesian Journal of Geology 8 (3): 135-141.

Sutikno., Widiyanto., Santosa, L.W. dan Purwanto, T.H. 2007. Kerajaan Merapi, Sumberdaya Alam dan Daya Dukungnya. Yogyakarta: BPFG.

Sutton, J., dan Tierney, K. 2006. Disaster Preparedness: Concepts, Guidance, and Research. Natural Hazards Center, Institute of Behavioral Science, University of Colorado.

Verstappen, H. Th. 2013. Garis Besar Geomorfologi Indonesia, Terjemahan oleh Sutikno. Yogyakarta: Gadjah Mada University Press.

Widayani, P dan Tim KKN-PPM UGM. 2011. Penyusunan Basis Data Spasial Sumberdaya Air Melalui Partisipasi Masyarakat, Studi Kasus di Desa Kepuharjo Kecamatan Cangkringan Kabupaten Sleman Provinsi Daerah Istimewa Yogyakarta. Gea 11 (1): 13-25. 